\title{
Temperature and light requirements for germination of species of Velloziaceae from different Brazilian rocky outcrops
}

\author{
Elisa Monteze Bicalho" ${ }^{1 *}$, Letícia A. Soares-da-Mota ${ }^{2}$ and Queila Souza Garcia
}

Received: August 22, 2017

Accepted: December 6, 2017

\begin{abstract}
Germination is the first step to successful plant establishment. The range of factors that promote germination varies among species. Light and temperature requirements for the germination of species of Velloziaceae were investigated. Seeds of Barbacenia flava, B. markgrafii, B. purpurea, B. williamsi, Vellozia alata, V. compacta, V. glochidea and V. plicata were collected from rocky outcrops located in different Brazilian states and were incubated for germination at 10 to $40{ }^{\circ} \mathrm{C}$ in light or dark conditions. Seed mass and length were measured for each species. In general, all species exhibited a high germination percentage at temperatures of $15-40^{\circ} \mathrm{C}$ in the light, with the optimal temperature being $25-30{ }^{\circ} \mathrm{C}$ for species of Barbacenia and $30^{\circ} \mathrm{C}$ for species of Vellozia. Barbacenia flava, V. compacta and, particularly, B. markgrafii, germinated in the dark. In contrast, $B$. purpurea exhibited an absolute requirement for light and the most restricted range of temperature to germinate. Germination responses and seed traits were related to the microclimate where the species were collected, and germinability in darkness is likely a common trait for species of Velloziaceae from the Espinhaço Range.
\end{abstract}

Keywords: Barbacenia, darkness, granitic outcrops, inselbergs, ironstone outcrops, optimal temperature, quarzitic outcrops, Vellozia

\section{Introduction}

Seed germination is one of the most important steps in the life cycle of a plant and it depends on a combination of seed traits and environmental factors (Bewley et al. 2013). Besides water and oxygen, light and temperature are considered important requirements for germination onset (Baskin \& Baskin 1998). Seed size and mass can strongly influence germination requirements and timing, mainly with regard to light. In general, small seeds require light to germinate (Bewley et al. 2013). Light signals germination to begin (and the termination of dormancy) by interacting with the phytochrome and the control of the main phytormones involved in germination, specifically the germination inductor gibberellin and the dormancy maintainer abscisic acid (Finch-Savage \& Leubner-Metzger 2006). The role of temperature in seed germination is related to membrane permeability, which improves enzyme activity and increases respiratory metabolism, and thus the rate of germination (Bewley et al. 2013).

It is common that, for some species, a combination of environmental factors determines the timing of seed germination (Baskin \& Baskin 1998). The manner by which seeds respond to combinations of factors can be phylogenetically conserved and highly dependent on their niches (Donohue et al. 2010). Some peculiar environments, such as rocky outcrops, possess soil with sets of characteristics that contribute to endemism (Dayrell et al. 2016; Hopper et al. 2016; Silveira et al. 2016). Therefore, species from rocky outcrops would be expected to have a requirement for specific cues for germination.

1 Departamento de Botânica, Instituto de Ciências Biológicas, Universidade Federal de Minas Gerais, 31270-901, Belo Horizonte, MG, Brazil 2 Faculdade Pitágoras de Belo Horizonte, 30441-194, Belo Horizonte, MG, Brazil

* Corresponding author: embicalho@gmail.com 
Specific botanical families occur on most rocky outcrops. For example, species of the family Velloziaceae are found on rocky outcrops or sandy soils, which explains their xeromorphic characteristics (Salatino et al. 2001). The majority of the described species of Velloziaceae are endemic to Brazil (Giulietti et al. 2005), and most of these are found in the Central Plateau (Mello-Silva 1995; Mello-Silva et al. 2011). For these reasons, and due to niche disruption by anthropogenic activities, some members of this family were included in the Brazilian list of endangered species (Fundação Biodiversitas 2008) or found to be in need of additional information regarding their life cycle and distribution to deserve more attention from conservation authorities (MMA 2008).

We investigated seed germination of eight species of Velloziaceae from different Brazilian rocky outcrops (with substrates varying among quartzite, granite and ironstone and climates varying from tropical to tropical altitudinal mesothermic) located in multiple different Brazilian states. We aimed to determine the light and temperature requirements for germination in relation to local occurrence and the particular traits of each species in order to understand the process of seedling recruitment. This study provides useful information for developing future efforts and strategies for biodiversity conservation, mainly regarding species of Velloziaceae, and the restoration of the rocky outcrops.

\section{Materials and methods}

\section{Plant material, collection areas and seed characterization}

Fruits of Barbacenia flava Mart. ex Schult. \& Schult.f. and Vellozia alata L.B.Sm. were collected in Serra do Cipó National Park; B. markgrafii Schulze-Menz in Biribiri State Park; B. williamsi L.B.Sm. in Serra do Curral; and V. compacta Mart. in Serra do Rola Moça State Park. All these localities are in the state of Minas Gerais and are part of the campos rupestres (rocky grasslands) of Cadeia do Espinhaço, which has a climate classified as $C w b$, by the Köppen system, which is characterized as tropical altitudinal mesothermic with a rainy spring-summer and a dry autumn-winter (Köppen 1900; Alvares et al. 2013). Annual precipitation is around $1200 \mathrm{~mm}$ and is concentrated during the spring-summer season. Temperature ranges between 15 (average minimum in the coldest season) and $25^{\circ} \mathrm{C}$ (average maximum in the warmest season) and the mean elevation is $900 \mathrm{~m}$ above sea (revised by Silveira et al. 2016).

Fruits of B. purpurea Hook. were collected at Pedra da Urca, an inselberg located in the municipality of Rio de Janeiro (state of Rio de Janeiro), which has a climate classified as Af, by to Köppen system (Köppen 1900; Alvares et al. 2013), which is characterized as warm tropical with low temperature fluctuations and high humidity throughout the seasons. Annual precipitation is around $1300 \mathrm{~mm}$ and temperature ranges between 20 and $30^{\circ} \mathrm{C}$ (INMET 2014).

Fruits of $V$. glochidea Pohl were collected in Serra dos Carajás (municipality of Parauapebas, state of Pará) whose climate is Aw according to Köppen system (Köppen 1900; Alvares et al. 2013), which is characterized as tropical with low temperature fluctuations and dry winters (precipitation $<100 \mathrm{~mm}$ ). The annual precipitation is above $2000 \mathrm{~mm}$ and temperature ranges between 21 and $25{ }^{\circ} \mathrm{C}$ (Corrêa 2011). Vellozia plicata Mart. was collected in an inselberg in Vitória city (Espírito Santo), which is classified as Am, by the Köppen system (Köppen 1900; Alvares et al. 2013), which is characterized as tropical with low temperature fluctuations and less-dry winters (precipitation $>100 \mathrm{~mm}$ ). Temperature ranges between 23 and $30^{\circ} \mathrm{C}$ and annual precipitation is around $1100 \mathrm{~mm}$ (INMET 2014).

Fruits were removed from the plants in at least 100 matrices per species located in rocky outcrops at the moment of seed dispersion (December to March for all species). Then the fruits were broken, processed to separate the seeds, and the seeds measured for length and dry mass (Tab. 1). For each species, 100 seeds were measured for length and 25 to 50 seeds were weighed before and after drying at $105^{\circ} \mathrm{C}$ for 24 hours (MAPA 2009). The seeds were used immediately in subsequent germination experiments. The results of germination tests were also considered to measure seed viability.

\section{Germination experiments}

Germinability was tested under constant temperatures in light and dark conditions. Four replicates of 25 seeds were used for each temperature and light/dark treatment. Seeds were placed in Petri dishes with a double layer of germination paper moistened with nystatin solution $(0.1 \%)$ to control fungal infestation (nystatin was previously tested and found to have no effects on germination). Petri dishes were kept moistened with nystatin solution during the entire experiment to avoid losses due to desiccation. The Petri dishes were distributed among germination chambers set at $15,20,25,30,35$ and $40^{\circ} \mathrm{C}$ under a photoperiod of 12 hours $\left(40 \mu \mathrm{mol}\right.$ photon $\left.\mathrm{m}^{-2} \mathrm{~s}^{-1}\right)$ or in darkness (wrapped in aluminum foil and placed within black plastic bags). The seeds were evaluated daily for 30 days, with the criterion of germination being radicle protrusion of $2 \mathrm{~mm}$. The Petri dishes kept under dark conditions were evaluated daily in a dark room under green light because it is considered safe for observation of darkness treatments (Vieira et al. 2017a). The resulting data were used to calculate germination percentage and mean germination time. The optimal temperature for seed germination was considered the temperature that promoted the highest germination percentage in the shortest time (sensu Labouriau 1983). 
Table 1. Sample locality, type of substrate, length and dry mass (means \pm SD) of four species of Barbacenia and Vellozia seeds collected in Brazilian States, Minas Gerais (MG), Rio de Janeiro (RJ), Pará (PA) and Espírito Santo (ES).

\begin{tabular}{|c|c|c|c|c|c|c|c|}
\hline Species & Sample locality & Coordinates & State & Substrate/soil & Altitude (m) & Lenght (mm) & Dry mass (mg) \\
\hline Barbacenia flava & $\begin{array}{l}\text { Parque Nacional da } \\
\text { Serra do Cipó }\end{array}$ & $\begin{array}{l}19^{\circ} 12^{\prime}-19^{\circ} 34^{\prime} \mathrm{S} \\
43^{\circ} 27^{\prime}-43^{\circ} 38^{\prime} \mathrm{W}\end{array}$ & $\mathrm{MG}^{*}$ & Quartzite outcrops & 900 & $2.11 \pm 0.28$ & $1.21 \pm 0.09$ \\
\hline Barbacenia markgrafii & $\begin{array}{l}\text { Parque Estadual de } \\
\text { Biribiri }\end{array}$ & $\begin{array}{l}18^{\circ} 14^{\prime} 53^{\prime \prime}-18^{\circ} 02^{\prime} 15^{\prime \prime} \mathrm{S} \\
43^{\circ} 39^{\prime} 57^{\prime \prime}-43^{\circ} 29^{\prime} 36^{\prime \prime} \mathrm{W}\end{array}$ & $\mathrm{MG}^{*}$ & Quartzite outcrops & 1200 & $1.16 \pm 0.23$ & $0.18 \pm 0.005$ \\
\hline Barbacenia purpurea & $\begin{array}{c}\text { Pedra da Urca, Rio de } \\
\text { Janeiro }\end{array}$ & $\begin{array}{l}22^{\circ} 57^{\prime} 5^{\prime \prime} \mathrm{S} \\
43^{\circ} 9^{\prime} 50^{\prime \prime} \mathrm{W}\end{array}$ & RJ & Granite outcrops & 220 & $1.54 \pm 0.19$ & $0.20 \pm 0.004$ \\
\hline Barbacenia williamsi & $\begin{array}{l}\text { Serra do Curral, Belo } \\
\text { Horizonte }\end{array}$ & $\begin{array}{l}19^{\circ} 57^{\prime} 39^{\prime \prime S} \\
43^{\circ} 54^{\prime} 35^{\prime \prime} \mathrm{W}\end{array}$ & $\mathrm{MG}^{*}$ & Ironstone outcrops & 1200 & $2.05 \pm 0.34$ & $0.13 \pm 0.004$ \\
\hline Vellozia alata & $\begin{array}{l}\text { Parque Nacional da } \\
\text { Serra do Cipó }\end{array}$ & $\begin{array}{l}19^{\circ} 12^{\prime}-19^{\circ} 34^{\prime} \mathrm{S} \\
43^{\circ} 27^{\prime}-43^{\circ} 38^{\prime} \mathrm{W}\end{array}$ & $\mathrm{MG}^{*}$ & Quartzite outcrops & 900 & $2.62 \pm 0.31$ & $3.76 \pm 0.32$ \\
\hline Vellozia compacta & $\begin{array}{l}\text { Parque Estadual da } \\
\text { Serra do Rola Moça }\end{array}$ & $\begin{array}{l}20^{\circ} 02^{\prime} 34.6 " \mathrm{~S} \\
44^{\circ} 0^{\prime} 23.2^{\prime \prime} \mathrm{W}\end{array}$ & $\mathrm{MG}^{*}$ & Ironstone outcrops & 1300 & $1.05 \pm 0.14$ & $0.20 \pm 0.02$ \\
\hline Vellozia glochidea & Serra de Carajás & $\begin{array}{c}6^{\circ} 6^{\prime} 29^{\prime \prime} \mathrm{S} \\
50^{\circ} 18^{\prime} 16^{\prime \prime} \mathrm{W}\end{array}$ & PA & Ironstone outcrops & 900 & $2.29 \pm 0.32$ & $1.24 \pm 0.18$ \\
\hline Vellozia plicata & Vitória & $\begin{array}{l}20^{\circ} 19^{\prime} 20^{\prime \prime} \mathrm{S} \\
40^{\circ} 20^{\prime} 17^{\prime \prime} \mathrm{W}\end{array}$ & ES & Granite outcrops & 0 & $2.03 \pm 0.32$ & $0.15 \pm 0.03$ \\
\hline
\end{tabular}

*Espinhaço Mountain Range

\section{Statistical analysis}

Data of germination percentage and mean germination time were submitted to GLM two-way ANOVA considering "temperature" and "light or darkness conditions" as factors. When significant, the differences between means were compared by Newman-Keuls post-hoc test with the $P$ value set at $5 \%$ probability. Germination percentage in light and darkness and mean germination time in both conditions were also used in a multivariate cluster analysis (UPGMA) based on the Euclidian distance in percentage

\section{Results}

\section{Temperature and light requirements for germination in Velloziaceae}

In general, all species of Velloziaceae studied here exhibited high germination percentages under light and at most of the temperatures tested (Fig. 1). Regarding the species of Barbacenia, in the light $B$. flava had more than $90 \%$ of its seeds germinate from 15 to $35^{\circ} \mathrm{C}$, but none of its seeds germinated at 10 and $40{ }^{\circ} \mathrm{C}$. In the dark, the highest germination percentages for $B$. flava seeds were at 30 and $35^{\circ} \mathrm{C}$ (optimal temperatures, Fig. 2), with no statistical differences between germination percentage of light and dark at $35^{\circ} \mathrm{C}$ (Fig. 1). Barbacenia markgrafii exhibited germination in all temperatures in the light and from 15 to $40{ }^{\circ} \mathrm{C}$ in the dark, but the percentages were higher in the light, with the exception of $30^{\circ} \mathrm{C}$ for which no differences were found in relation to the dark (Fig. 1). For this species the optimal temperatures were 25 and $30^{\circ} \mathrm{C}$ in the light and $30^{\circ} \mathrm{C}$ in the dark (Fig. 2). Barbacenia purpurea exhibited 93 to $99 \%$ germination from 15 to $30^{\circ} \mathrm{C}$ in the light, with $25^{\circ} \mathrm{C}$ being the optimal temperature (Fig. 2), and no germination at 35 and $40^{\circ} \mathrm{C}$ (light); there was no germination by this species at any temperature in the dark (Fig. 1). For B. williamsi, germination was above $94 \%$ from 15 to $30^{\circ} \mathrm{C}$, diminishing at 35 and $40^{\circ} \mathrm{C}$, in the light; less than $10 \%$ germinated in the dark (Fig. 1). For this species, the optimal temperatures for germination in the light were 25 and $30^{\circ} \mathrm{C}$ (Fig. 2).

Regarding the species of Vellozia, $V$. alata exhibited high germination in the light from 20 to $40^{\circ} \mathrm{C}$, and no germination at 10 and $15^{\circ} \mathrm{C}$. Germination was no greater than $16 \%$ for this species in the dark from 25 to $40{ }^{\circ} \mathrm{C}$ (Fig. 1). Germination was fastest in the light at $30^{\circ} \mathrm{C}$, which was considered the optimal temperature (Fig. 2). The seeds of $V$. compacta exhibited high germination in all temperatures tested, except for $10^{\circ} \mathrm{C}$ in the light, with the optimal temperatures being 25 and $30{ }^{\circ} \mathrm{C}$ (Fig. 2). In the dark, germination percentage increased gradually from 25 to $40^{\circ} \mathrm{C}$ (Fig. 1) for this species. For V. glochidea, germination was less than $70 \%$ in the light, with no germination at $10^{\circ} \mathrm{C}$. In the dark, this species exhibited germination only at 35 and $40{ }^{\circ} \mathrm{C}$ (Fig. 1). The optimal temperatures for germination of $V$. glochidea was 25 and $30^{\circ} \mathrm{C}$ (Fig. 2). For V. plicata, germination in the light was null at $10^{\circ} \mathrm{C}$, low at $15^{\circ} \mathrm{C}$ and optimal at $30^{\circ} \mathrm{C}$ (Fig. 2). In the dark, germination of $V$. plicata occurred from 30 to $40^{\circ} \mathrm{C}$, being higher at $40{ }^{\circ} \mathrm{C}$ (Fig. 1).

\section{The influence of seed traits on germination}

The greatest seed mass and length were for V. alata (Tab. 1), although seeds of all species of Velloziaceae studied were relatively small (low mass and short length). The variables germination percentage in the light, germination percentage in the dark, seed mass and seed length, grouped the species 


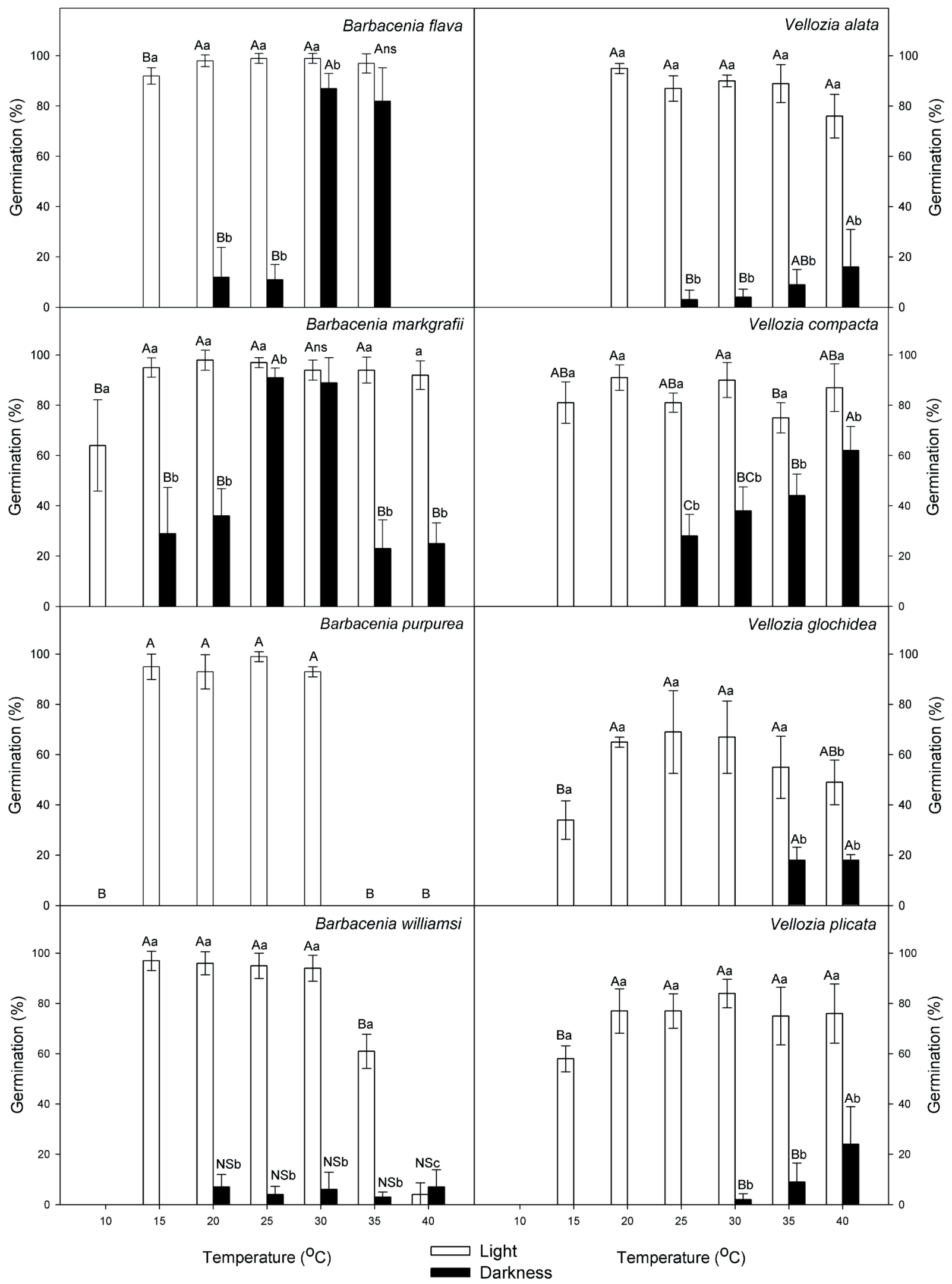

Figure 1. Germination percentage of Barbacenia (left) and Vellozia (right) species at 15, 20, 25, 30, 35 and $40^{\circ} \mathrm{C}$ in the light (white bars) and in the dark (black bars). Bars are mean \pm standard deviation of 4 replicates. Uppercase compares different temperatures in light or darkness conditions and lowercase compares light and darkness conditions in the same temperature. NS, non-significant. 

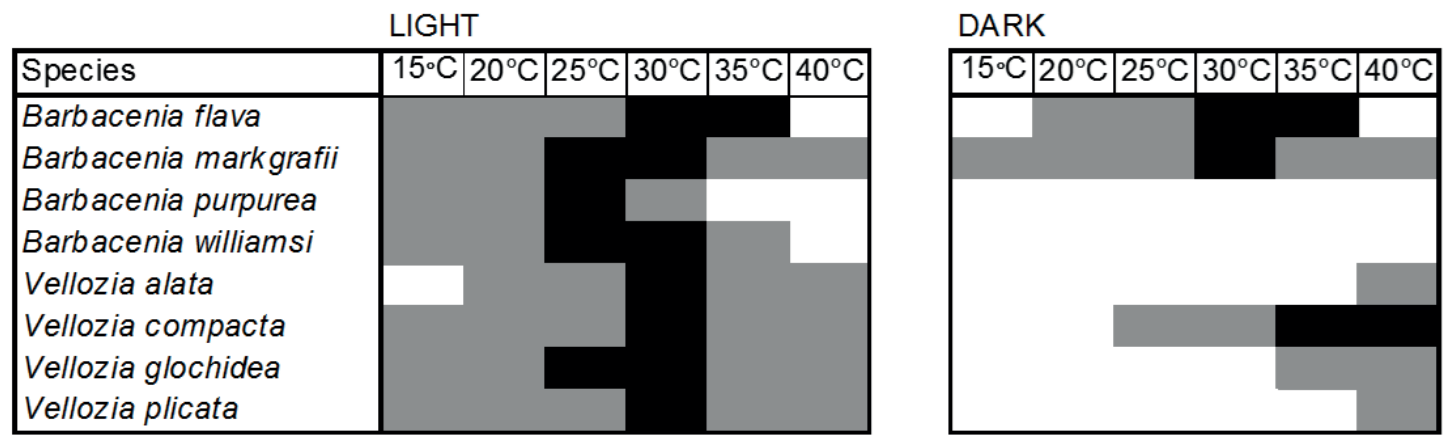

Optimal temperature for germination

Germination upper than $10 \%$

Figure 2. Optimal (in black) and average (gray) ranges of temperature for germination of Barbacenia and Vellozia species in the light and in the dark. The optimal germination temperature was defined as that temperature showing the greatest germinability associated with the greatest germination velocity.

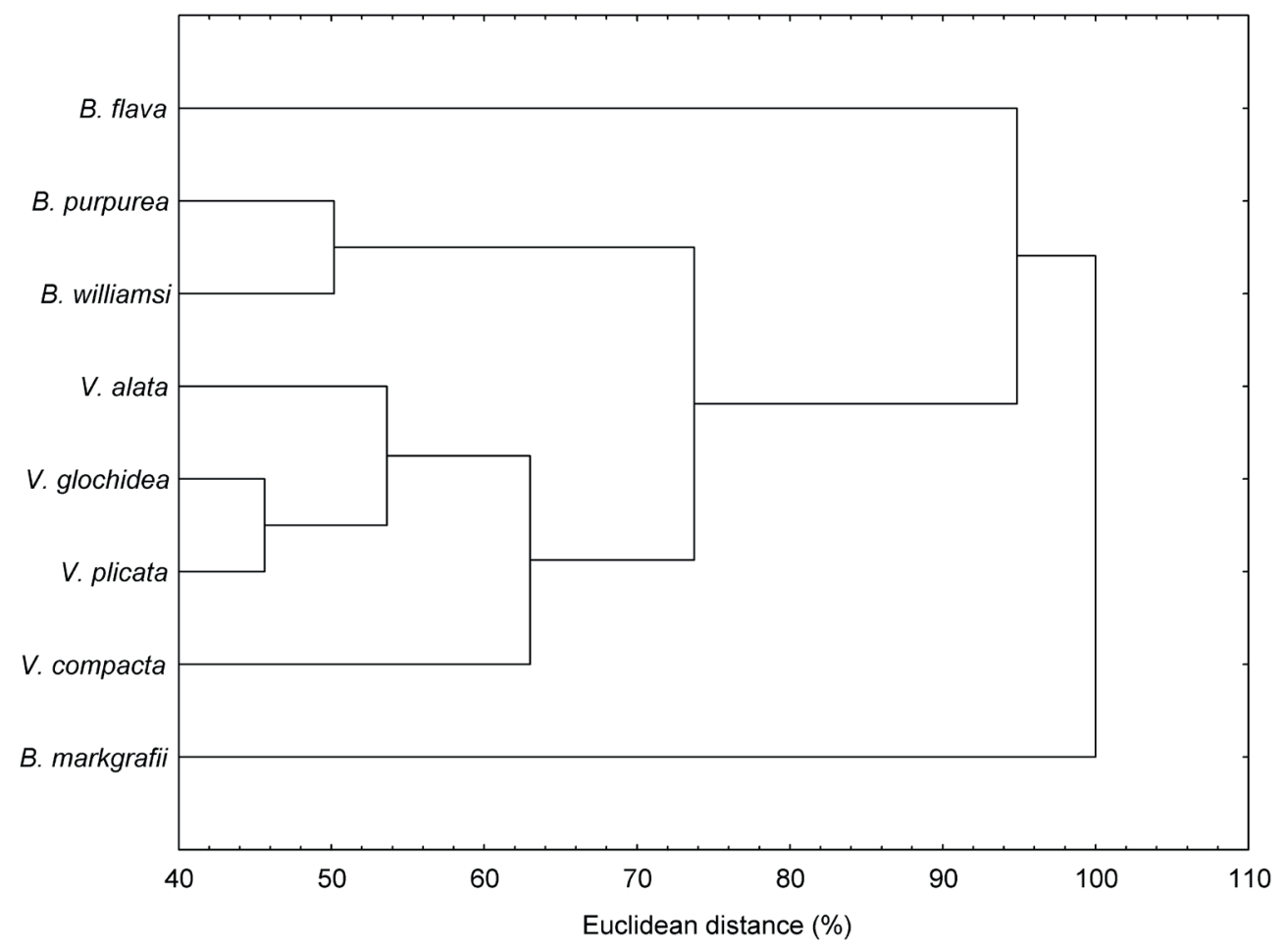

Figure 3. Grouping analysis of Velloziaceae species based on the germination percentage in light, dark and seed traits (mass and length).

as shown in Figure 3. The lowest level of dissimilarity was between V. glochidea and V. plicata, followed by B. purpurea and B. williamsi. Barbacenia markgrafii exhibited the greatest level of dissimilarity with the other species (Fig. 3).

\section{Discussion}

We report the distinct light and temperature requirements for seed germination of eight species from two genera of Velloziaceae: Barbacenia and Vellozia. The requirement of light for germination has been reported for other species of Velloziaceae (Garcia \& Diniz 2003; Garcia et al. 2007; Munné-Bosch et al. 2011; Soares-da-Mota \& Garcia 2013; Vieira et al. 2017a), and was confirmed here. Based on length and mass, the seeds studied here are considered small relative to other known species. The requirement for light by small seeds prevents germination when the seeds are too deep in the soil for seedlings to reach the surface due to limited nutrients stored in seed tissues (Pons 1992; 
Schütz \& Rave 1999). The wide range of temperatures that were found suitable for germination, 15 to $40^{\circ} \mathrm{C}$, in almost all species is an important adaptation to environments in which the temperature can range $20^{\circ} \mathrm{C}$ during the course of a year (Orozco-Almanza et al. 2003), as happens with the rocky outcrops where the studied species of Velloziaceae occur.

If the range of temperature in which seeds can germinate is large, it means the level of dormancy is very low or nonexistent (Baskin \& Baskin 1998). Therefore, the species studied here did not show primary dormancy, which suggests that recruitment from seeds is widely spread over different microhabitats. Based on the optimal temperature for germination, $25-30^{\circ} \mathrm{C}$ for Barbacenia and $30^{\circ} \mathrm{C}$ for Vellozia (Fig. 2), and the timing of dispersion in early summer (when temperatures reach above $25^{\circ} \mathrm{C}$ in the environments where the species studied here were collected), there could be a synchrony of germination after dispersion. Moreover, it is probably not a coincidence that the optimal temperature range for germination of all the studied species is the same as the temperature range of the microenvironments where they were collected. As revised by Donohue et al. (2010), the width of the germination niche and the species ecological or geographic range are, in some cases, closely related even if they are out of their wild environment. Indeed, spring-summer is the rainy season in all microclimates and environments in which the species were collected, indicating a wide window of climatic conditions (including high water potential of the soil and adequate temperature) for seed germination and seedling establishment. Seeds that remain could still be recruited in the next rainy season, when the minimal environmental conditions (at least water and adequate temperature) for germination coexist. Furthermore, species of Velloziaceae have been reported to build persistent soil seed banks (Munné-Bosch et al. 2011; Garcia et al. 2017) without, however, performing dormancy cycles (Garcia et al. 2017), reinforcing the hypothesis of recruitment over time. Interestingly, seeds of some species, especially $B$. markgrafii, $B$. flava and $V$. compacta, germinated in the dark (Fig. 1). Regarding the species of Vellozia studied here, we observed increasing germination percentage with increasing temperatures in the dark. Recently, Vieira et al. (2017b) demonstrated that germination in the dark by species of Vellozia submitted to high temperature $\left(40{ }^{\circ} \mathrm{C}\right)$ was related to a decrease in abscisic acid (ABA) levels due to $\mathrm{ABA}$ catabolism, while at low temperature $\left(25^{\circ} \mathrm{C}\right)$ the de novo synthesis of $A B A$ was promoted. Our results, and those from Vieira et al. (2017b), point out a unique trait of some species of Velloziaceae germination at warm temperatures independently of light.

Regarding traits of individual species, B. markgrafii showed high germination percentages from the lowest $\left(10^{\circ} \mathrm{C}\right)$ to the highest $\left(40^{\circ} \mathrm{C}\right)$ temperatures tested, including 25 and $30{ }^{\circ} \mathrm{C}$ in the dark. These responses, added to seed length and mass, separated this species as more dissimilar from the others, including those of the same genus. On the other hand, $B$. purpurea had the most restricted germination temperature range and, interestingly, did not germinate in conditions of darkness. The population studied was located on an inselberg in the Brazilian littoral zone and had small seeds and photoblastism, which, according to Pearson et al. (2002), are in line with pioneer species. This species was very similar to $B$. williamsi, which exhibited high germinability from 15 to $30^{\circ} \mathrm{C}$, as did B. purpurea. These differences highlight the wide germinability of species of Barbacenia found in the present study, from very restricted to broad temperature and light conditions.

Altogether, our results point-out a common trait among species of Velloziaceae from the rocky outcrops of the Cadeia do Espinhaço (Cwb, tropical mesothermic climate): the capacity to germinate in conditions of darkness (see Tab. 1, Fig. 1). Our findings are in agreement with those of Soares-da-Mota \& Garcia 2013 and Vieira et al. (2017a), whose studied species that germinated in the dark were also collected from Cadeia do Espinhaço. Additionally, the lowest dissimilarity level was found between $V$. glochidea and $V$. plicata, both of which exhibited similar germination in the dark at the highest temperatures, and both were collected in a tropical climate (Aw and Am according to Köppen system). Adding the responses of B. purpurea to this observation, species from " $\mathrm{A}$ " climate (less temperature fluctuations over the seasons, according to Köppen system) seem to have an absolute requirement for light to germinate. Thus, the similarities found among species here might be more related to climate than to the substrate of the rocky outcrops where the species were from.

In conclusion, our findings reaffirmed the requirement of light for germination and the capacity to germinate in conditions of darkness for some species of Velloziaceae. Moreover, we confirmed the absence of primary dormancy in the studied species, which is in line with other studies. We found differences in germination responses among species of Barbacenia and Vellozia, and among species from different climates and substrates. The similarities found in germination responses may be related to microclimate. Regarding light and temperature requirements for germination, B. markgrafii and B. purpurea deserve further investigation due to the contrasting differences found between them. Altogether, the high germinability of the seeds of the species of Velloziaceae studied here over a large range of temperatures, including in the dark, point to the possibility of long-term recruitment. Furthermore, germination, and probably seedling establishment, seem to be finely regulated and synchronized by the specific temperature window typical of tropical and tropical mesothermic climates. Considering a scenario of increasing temperatures as a result of climate change, the wide range of germination traits of the species studied here will probably allow their establishment with minimal consequences to their germination niches, as pointed out by Soares-da-Mota 
\& Garcia (2013). However, changes to the rainy season with prolonged droughts would probably be a major challenge for plant regeneration of these species. Therefore, it is reasonable to expect that altered environmental conditions will probably not change the germination niches of the species of Velloziaceae reported here.

\section{Acknowledgements}

The authors thank Dr. Fábio Vieira for collecting of Vellozia glochidea seeds. Finnantial support was conceded from Fundação O Boticário de Proteção à Natureza and Fundação de Amparo à Pesquisa no Estado de Minas Gerais (FAPEMIG). L. A. Soares-da-Mota and E.M. Bicalho received grant awards from Coordenação de Aperfeiçoamento de Pessoal de Nível Superior (CAPES) and Q. S. Garcia received a research productivity scholarship from Conselho Nacional de Desenvolvimento Científico e Tecnológico (CNPq).

\section{References}

Alvares CC, Stape JL, Sentelhas PC, Gonçalves JLM, Sparovek G. 2013. Köppen's climate classification map for Brazil. Meteorologische Zeitschrift 22: 711-728.

Baskin CC, Baskin JM. 1998. Seeds: ecology, biogeography, and evolution of dormancy and germination. San Diego, Elsevier.

Bewley JD, Bradford K, Hilhorst H, Nonogaki H. 2013. Seeds - physiology of development, germination and dormancy. New York, Springer-Verlag.

Corrêa GR. 2011. Pedogênese em platôs de canga ferrífera e basaltos na Serra dos Carajás - PA. PhD Thesis, Universidade Federal de Viçosa, Viçosa.

Dayrell RLC, Garcia QS, Negreiros D, Baskin CC, Baskin JM, Silveira FAO. 2016. Phylogeny strongly drives seed dormancy and quality in a climatically buffered hotspot for plant endemism. Annals of Botany 119: 267-277.

Donohue K, Casas RR, Burghardt L, Kovack K, Willis CG. 2010. Germination, postgermination adaptation, and species ecological ranges. Annual Review of Ecology, Evolution and Systematics 41: 293-319.

Finch-Savage WE, Leubner-Metzger G. 2006. Seed dormancy and the control of germination. New Phytologist 171: 501-523.

Fundação Biodiversitas. 2008. Lista de espécies da Flora brasileira ameaçadas de extinção. Belo Horizonte, Fundação Biodiversitas. http://www.biodiversitas.org.br/floraBr/grupo3fim.asp

Garcia QS, Diniz ISS. 2003. Comportamento germinativo de três espécies de Vellozia da Serra do Cipó, MG. Acta Botanica Brasilica 17: 487-494.

Garcia QS, Jacobi CM, Ribeiro BA. 2007. Germination response of two species of Vellozia (Velloziaceae) from the "campos rupestres" of Minas Gerais, Brazil. Acta Botanica Brasilica 21: 451-456.

Garcia QS, Saraiva IS, Soares-da-Mota LA, Bicalho EM. 2017. Long-term persistence of Velloziaceae species in the soil seed bank in campo rupestre vegetation, Brazil. Plant Ecology \& Diversity 10: 323-328.
Giulietti AM, Harley RM, Queiroz LP, Wanderley MGL, Berg C. 2005. Biodiversity and conservation of plants in Brazil. Conservation Biology 19: 632-639.

Hopper SD, Silveira FAO, Fiedler PL. 2016. Biodiversity hotspots and Ocbil theory. Plant and Soil 403: 167-216.

INMET - Instituto Nacional de Meteorologia. 2014. BDMEP - Banco de Dados Meteorológicos para Ensino e Pesquisa. Brasília, INMET. http:// www.inmet.gov.br/portal/index.php?r=bdmep/bdmep

Köppen W. 1900. Versuch einer klassifikation der klimate, vorzugsweise nach ihren Beziehungen zur Pflanzenwelt. Geographische Zeitschrift 6: 593-611.

Labouriau LG. 1983. A germinação das sementes. Washington DC, Secretaria Geral da Organização dos Estados Americanos.

Mello-Silva R. 1995. Aspectos taxonômicos, biogeográficos, morfológicos e biológicos das Velloziaceae de Grão-Mogol, Minas Gerais, Brasil. Boletim de Botânica da Universidade de São Paulo 14: 49-79.

Mello-Silva R, Santos DYAC, Salatino MLF, et al. 2011. Five vicarious genera from Gondwana: the Velloziaceae as shown by molecules and morphology. Annals of Botany 108: 87-102.

MAPA - Ministério da Agricultura Pecuária e Abastecimento. 2009. Regras para análise de sementes. Brasília, MAPA/ACS.

MMA - Ministério do Meio Ambiente. 2008. Lista oficial de espécies ameaçadas. Instrução Normativa $\mathrm{n}^{\circ} 6$ de 23 de setembro de 2008. Brasília, MMA. http://www.mma.gov.br/estruturas/ascom_boletins/_ arquivos/83_19092008034949.pdf

Munné-Bosch S, Oñate M, Oliveira PG, Garcia QS. 2011. Changes in phytohormones and oxidative stress markers in buried seeds of Vellozia alata. Flora - Morphology, Distribution, Functional Ecology of Plants 206: 704-711.

Orozco-Almanza MS, León-García LP, Grether R, García-Moya E. 2003. Germination of four species of the genus Mimosa (Leguminosae) in a semi-arid zone of Central Mexico. Journal of Arid Environments 55: 75-92.

Pearson TRH, Burslem DFRP, Mullins CE, Dalling JW. 2002. Germination ecology of neotropical pioneers: interacting effects of environmental conditions and seed size. Ecology 83: 2798-2807.

Pons TL. 1992. Seed responses to light. In: Fenner M. (ed.) Seed: the ecology of regeneration in plant communities. New York, CAB International. p. 259-284.

Salatino A, Salatino MLF, Mello-Silva R, Sluys M, Giannasi DE, Price RA. 2001. Phylogenetic inference in Velloziaceae using chloroplast trnL-F sequences. Systematic Botany 26: 92-103.

Schütz W, Rave G. 1999. The effect of cold stratification and light on the seed germination of temperate sedges (Carex) from various habitats and implications for regenerative strategies. Plant Ecology 144: 215-230.

Silveira FAO, Negreiros D, Barbosa NPU, et al. 2016. Ecology and evolution of plant diversity in the endangered campo rupestre: a neglected conservation priority. Plant and Soil 403: 129-152.

Soares-da-Mota LA, Garcia QS. 2013. Germination patterns and ecological characteristics of Vellozia seeds from high-altitude sites in southeastern Brazil. Seed Science Research 23: 67-74.

Vieira BC, Rodrigues BM, Garcia QS. 2017a. Light exposure time and light quality on seed germination of Vellozia species (Velloziaceae) from Brazilian campo rupestre. Flora - Morphology, Distribution, Functional Ecology of Plants (in press). doi: doi.org/10.1016/j.flora.2017.01.012

Vieira BC, Bicalho EM, Munné-Bosch S, Garcia QS. 2017b. ABA regulates seed germination of Vellozia species in response to temperature. Plant Biology 19: 211-216. 